\title{
Rancangan Trucking Collaboration System
}

\author{
Muhammad Ibnu Choldun $\mathbf{R}^{\mathbf{1}}$, Sari Armiati ${ }^{2}$, Saptono Kusdanu Waskito ${ }^{3}$ \\ ${ }^{1,2}$ Program Studi D3 Manajemen Informatika, Politeknik Pos Indonesia, Bandung \\ ${ }^{3}$ Program Studi D3 Logistik Bisnis, Politeknik Pos Indonesia, Bandung \\ e-mail: ${ }^{1}$ ibnucholdun@poltekpos.ac.id, ${ }^{2}$ sariarmiati@poltekpos.ac.id, ${ }^{3}$ saptono@poltekpos.ac.id
}

\begin{abstract}
Abstrak
Perusahaan logistik bergerak di bidang jasa pengiriman memiliki kegiatan pengiriman dan penerimaan barang. Biasanya memiliki divisi Departemen Logistik yang bertanggung jawab untuk menangani pengembangan bisnis logistik, manajemen proyek logistik, termasuk pemilihan vendor, membuat laporan rekapitulasi tagihan dari vendor dan mengirimkan tagihan kepada pelanggan. Dalam penelitian ini pengamatan proses bisnis dilakukan di PT XYZ yang memiliki bisnis pengiriman barang. Proses bisnis yang terjadi saat ini, para vendor yang telah terdaftar di PT XYZ akan memberikan layanan transportasi untuk barang pengiriman yang dimiliki oleh mitra PT XYZ sesuai dengan dimensi jenis, volume, ukuran dan berat barang. Butuh waktu lama bagi Departemen Logistik untuk memilih vendor baru, rekapitulasi penagihan oleh admin penagihan juga dibuat dalam format yang berbeda dan tidak ada penyimpanan data yang tepat di Departemen Logistik. Berdasarkan kebutuhan ini, diperlukan desain aplikasi sistem kolaborasi truk (Trucking Collaboration System/TCS) di perusahaan PT XYZ yang memiliki kemampuan fungsional untuk mengelola data pemilihan vendor, mengelola rekapitulasi tagihan, dan melindungi data. Dalam tahapan analisis pemodelan menggunakan Business Process Modeling Notation (BMPN), sedangkan tahapan perancangan menggunakan Unified Modeling Language (UML). Desain aplikasi ini akan menjadi pedoman dalam mengimplementasikan perangkat lunak pada penelitian selanjutnya.
\end{abstract}

Kata kunci-rancangan, aplikasi, logistik, TCS, BPMN, UML

\begin{abstract}
Logistics company engaged in shipping services that have the activities of sending and receiving goods. Usually there is a Logistics Department division that is responsible for handling logistics business development, logistics project management, including vendor selection, making a bill recapitulation report from the vendor and sending bills to customers. In this study business process observations were carried out at PT XYZ which has a freight forwarding business. Business processes that occur at this time, the vendors that have been registered at PT XYZ will provide transportation services for shipping goods owned by PT XYZ partners according to dimensions of type, volume, size and weight of goods. It takes a long time for the Logistics Department to select a new vendor, the billing recapitulation by the billing admin is also made in different formats and there is no proper data storage in the Logistic Department. Based on these needs, we need a trucking collaboration system (TCS) application design at PT XYZ company that has the functional ability to manage vendor selection data, manage bill recapitulation, and protect data. In the analysis stage of modeling using Business Process Modeling Notation (BMPN), while the design stage uses Unified Modeling Language (UML). The design of this application will be a guideline in implementing software in the next research.
\end{abstract}

Keywords - application, design, logistic, TCS, BPMN, UML 


\section{PENDAHULUAN}

Pada saat ini perusahaan layanan logistik di Indonesia dalam menjalankan bisnisnya telah memberikan layanan kepada pelanggan dalam bidang; Project Logistic, Warehousing dan Transporting. Dengan target untuk mendapatkan omset maka perusahaan merasa perlu melakukan strategi yang jitu untuk dapat meraih pendapatan sesuai dengan target yang telah ditetapkan. Menurut hasil penelitian [1,2] terdapat tiga prioritas kebutuhan pelanggan yaitu pengiriman yang mudah dan tepat waktu, pelayanan yang cepat dan pengiriman yang aman di perusahaan freight forwarder. Sedangkan hasil penelitian $[3,4,5]$ menyebutkan tentang kebutuhan perancanaan transportasi yang matang di perusahaan forwarder akan meminimkan resiko permasalahan penjadwalan dan transportasi.

Beberapa langkah strategis yang ditempuh untuk dapat memberikan solusi total bagi pelanggannya dalam memberikan layanan jasa logistik, maka perusahaan melakukan strategi differensiasi. Dilihat dari kegiatannya, logistik meliputi kegiatan seperti pergudangan (warehouse), distribusi barang (distribution), transportasi barang (freigh transportation), dan pengelolaan pesanan (sales order processing).

Pada proses bisnis yang terjadi saat ini, para vendor yang sudah terdaftar di perusahaan logistik akan menyediakan layanan transportasi bagi pengiriman barang milik mitra perusahaan sesuai dengan dimensi jenis, volume, ukuran dan berat barang. Logistic Department memerlukan waktu yang lama untuk menyeleksi vendor baru, pembuatan rekapitulasi tagihan oleh billing admin pun dibuat dengan format yang berbeda-beda serta tidak amannya data-data yang tersimpan di Logistic Departement. Berdasarkan kebutuhan tersebut maka diperlukan sebuah rancangan aplikasi trucking collaboration system (TCS) pada perusahaan logistik yang memiliki kemampuan fungsional untuk mengelola data penyeleksian vendor, mengelola rekapitulasi tagihan, serta memproteksi data. Dengan dibangunnya sebuah trucking collaboration system sehingga memperoleh manfaat salah satunya adalah peningkatan dalam rantai pasok yaitu identifikasi titik kendali yang kritis, contohnya tempat, waktu dalam proses distribusi serta produksi dimana hal-hal salah dapat terjadi yang berkaitan erat dengan kualitas produk sehingga mempermudah proses monitoring dan menjamin sebuah sistem untuk menghasilkan kualitas yang konstan [6].

Adapun tujuan yang ingin dicapai dalam penelitian adalah teridentifikasinya model trucking collaboration system yang dapat digunakan sebagai basis rancangan aplikasi beserta analisis manfaatnya dan rumusan spesifikasi kebutuhan perangkat lunak serta dokumen perancangan aplikasi trucking collaboration system antara PT XYZ dan agent/vendor trucking. Penerapan rancangan sistem Trucking Collaboration System sebagai hasil penelitian memiliki peluang kontribusi. Sebagai kontribusi pengetahuan, rancangan trucking collaboration system didasari dari usulan model sistem informasi, arsitektur aplikasi dan dokumentasi kebutuhan fungsional yang formal. Dan sebagai kontribusi praktis, penerapan teknologi memberikan kontribusi berupa arsitektur aplikasi yang dapat dijadikan arahan merealisasikan aplikasi dengan menerapkan rancangan teknologi informasi. Lebih lanjut hasil dari penelitian dapat dijadikan basis perencanaan untuk pengembangan pangkalan data trucking system peneliti lain yang relevan dengan penelitian yang dilakukan.

\section{METODE PENELITIAN}

Metode penelitian yang akan dilakukan adalah sebagai berikut seperti terlihat pada gambar 1: 


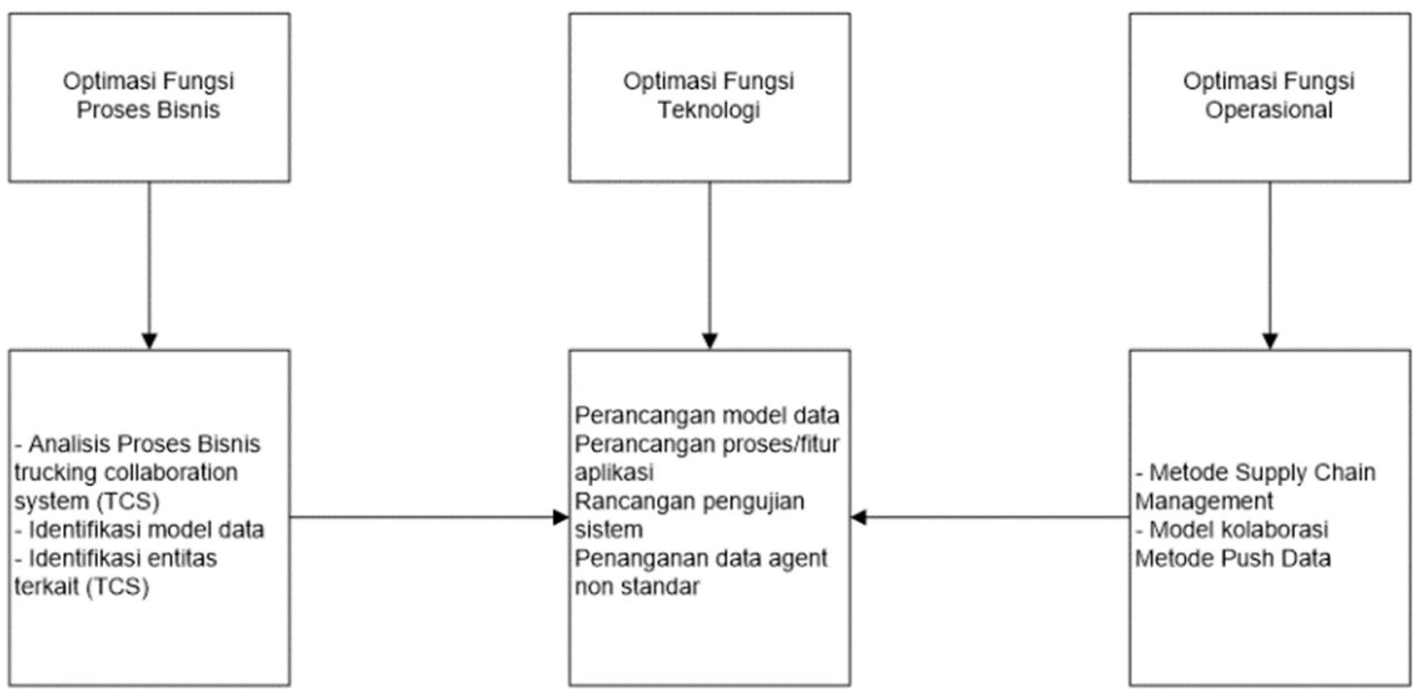

Gambar 1. Metode Penelitian TCS

Tahap penelitian dilakukan dari mulai perumusan optimasi fungsi proses bisnis, optimasi fungsi teknologi dan optimasi fungsi operasonal.

\section{A. Fungsi Proses Bisnis}

Studi literatur dilakukan untuk mendapatkan teori atau konsep, model maupun komponen yang relevan dengan masalah penelitian beserta metodologinya, termasuk best pratices yang telah dilakukan oleh industri tipikal. Tahap ini dilakukan untuk mendapatkan informasi tentang komponen-komponen yang perlu dirumuskan dalam membuat kolaborasi data dan penentuan harga. Berdasarkan studi pendahuluan dan studi literatur yang dilakukan maka dapat diperoleh gambaran variabel yang diperlukan dalam penelitian ini. Studi pendahuluan dilakukan di PT XYZ.

\section{B. Fungsi Teknologi}

Optimasi fungsi teknologi dilakukan dengan pendekatan mempelajari seluruh fungsi/fitur dan cara kerja dari setiap fungsi/komponen perangkat lunak yang sudah dimiliki oleh Balai dan PT XYZ dan memilih untuk dikolaborasikan/disinergikan menjadi solusi yang tepat dan sesuai dengan kondisi dan kebutuhan. Dengan metode pemeriksaan tersebut akan dapat diketahui secara pasti kinerja dari setiap fungsi tersebut apakah sudah sesuai dengan kriteria kebutuhan trucking collaboration system.

Sebagai landasan untuk penelitian berikutnya maka pada fase ini pun didefinisikan data flow diagram dan entity relationship diagram yang berasal dari fungsi proses bisnis yang dilakukan.

\section{Fungsi Operasional}

Optimasi fungsi operasional memberikan hasil sebagai masukan ke fase optimasi fungsi teknologi berupa metode push data yang dapat dilakukan di agent/vendor trucking maupun PT $\mathrm{XYZ}$ serta cara konsolidasi data bisnisnya.

\subsection{Analisis Sistem}

\section{HASIL DAN PEMBAHASAN}

Beberapa tips untuk melakukan proses freight forwarder menurut $[7,8]$ adalah menentukan kebutuhan secara keseluruhan, misal menentukan jumlah total biaya, bukan hanya 
biaya transortasi saja. Kemudian tentukan skala bisnis mitra dan vendor yang diajak berkolaborasi serta dukungan bisnisnya seperti sumber daya manusia, teknologi informasi dan kebutuhan pelaporannya.

Proses bisnis yang terjadi saat ini, para vendor yang sudah terdaftar di PT XYZ akan menyediakan layanan transportasi bagi pengiriman barang milik supplier PT XYZ sesuai dengan dimensi jenis, volume, ukuran dan berat barang yang sudah dibongkar muat. Pada analisis proses bisnis digunakan analisis rantai nilai dari Porter [9]. Analisis rantai nilai (value chain analysis) adalah proses di mana sebuah perusahaan atau organisasi mengidentifikasi kegiatan utama dan pendukung yang menambah nilai produk, kemudian menganalisisnya untuk mengurangi biaya atau meningkatkan diferensiasi. Analisis rantai merupakan strategi yang digunakan untuk mengalisis kegiatan internal organisasi. Dengan kata lain, dengan melihat ke dalam kegiatan internal, analisis itu mengungkap di mana keunggulan kompetitif suatu organisasi atau kekurangannya. Ketika sebuah perusahaan atau organiasi mampu memproduksi barang dengan biaya yang lebih rendah dari harga pasar atau untuk memberikan produk-produk unggulan, ia memperoleh keuntungan [10]. Rantai ini didefinisikan sebagai sekumpulan aktivitas bisnis dimana disetiap tahapan/langkah dalam aktivitas bisnis tersebut menambahkan nilai atau manfaat terhadap barang dan jasa organisasi yang bersangkutan. Jadi analisis rantai nilai Porter diadaptasi untuk menganalisis aktivitas spesifik dari trucking system sehingga dapat diketahui aktivitas utama dan aktivitas pendukungnya dengan tujuan akhirnya mendapatkan proses bisnis yang lebih efisien. Rantai nilai dari trucking collaboration system dapat dilihat pada gambar 2.

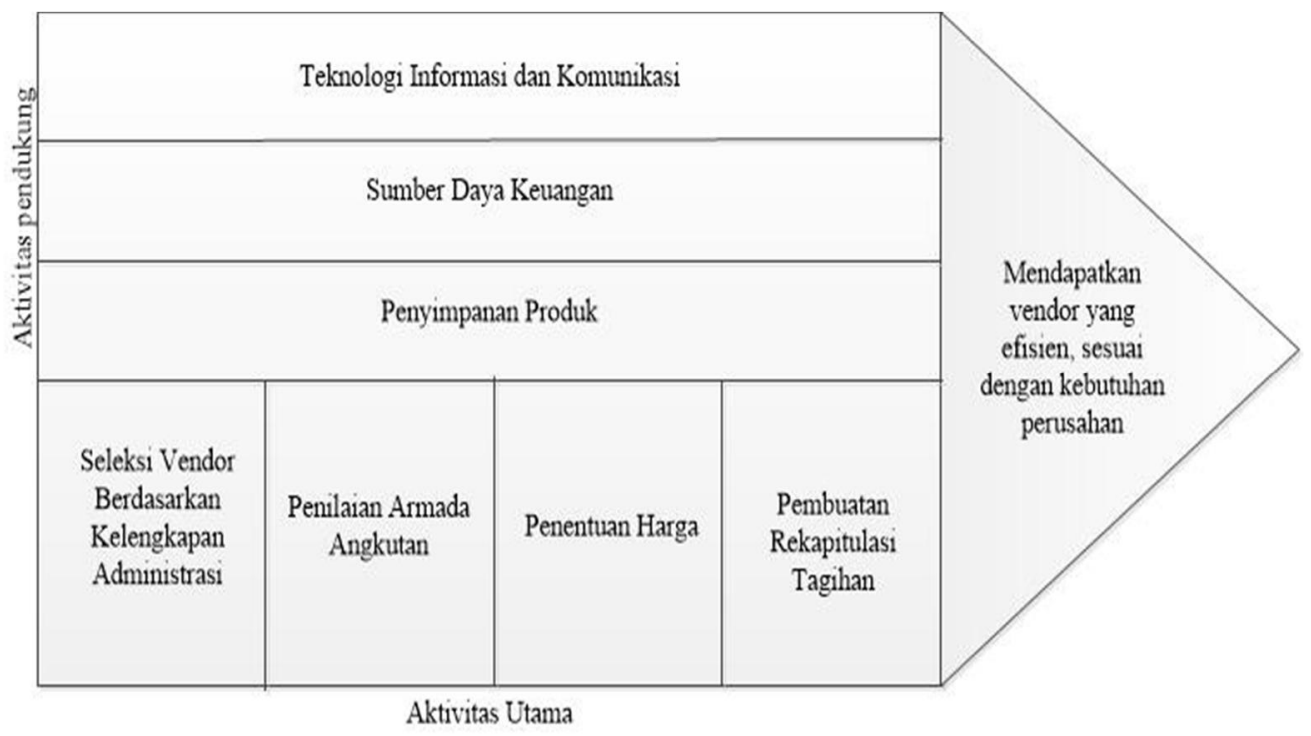

Gambar 2. Value Chain TCS

Rantai nilai pada gambar 2 memiliki jenis aktivitas sebagai berikut:

- Aktivitas Utama

1. Seleksi Vendor Berdasarkan Kelengkapan Administrasi

Dimulai dari pemberitaan mengenai tender, informasi tersebut disebarkan oleh tender admin melalui email, menelpon kolega-kolega terdekat, atau media lain, dalam kurun waktu tertentu tender tersebut dibuka dan selama waktu yang telah ditentukan tersebut, para vendor berusaha melengkapi semua persyaratan yang diminta Logistic Department. Setelah batas waktu habis, tender admin akan menyortir semua proposal yang masuk dengan mempelajari profil perusahaan, dan melihat dokumen-dokumen yang dilampirkan sebagai pelengkap dan 
yang memiliki value added. Ketika melakukan penyortiran ini akan didapat beberapa vendor yang terkadang belum melengkapi persyaratan sehingga harus dieliminasi dari tender.

2. Penilaian Armada Angkutan

Setelah semua data vendor yang memiliki kelengkapan berdasarkan administrasi, selanjutnya trucking supervisor akan melakukan peninjauan lapangan untuk melihat langsung armada angkutan yang dimiliki vendor. Jika masih didapat armada angkutan vendor yang kurang memenuhi syarat, misalnya kebutuhan akan QHSSE (Quality, Healthy, Security, and Safe Environtment) maka tender admin akan melakukan eliminasi yang kedua.

3. Penentuan Harga

Jika memenuhi syarat, selanjutnya trucking manager akan mempertimbang harga dan melakukan penawaran. Setelah proses itu selesai dan ada kesepakatan, maka dibuat sebuah perjanjian kerja antara vendor dan PT XYZ

4. Pembuatan Rekapitulasi Tagihan

Proses ini melibatkan perusahaan dan mitra pemilik barang yang akan menerima tagihan pembayaran jasa trucking dan pengiriman.

- Aktivitas Pendukung

1. Teknologi Informasi dan Komunikasi

Penggunaan teknologi informasi dan komunikasi akan dapat dilakukan perbaikan secara signifikan dalam akses in-transit inventory dan status kedatangan kiriman barang secara akurat baik lokasi maupun waktu pengirimannya (delivery time).

2. Sumber Daya Keuangan

Biaya transportasi terjadi karena penggunaan tenaga sopir (driver labor), konsumsi bahan bakar minyak (fuel), pemeliharaan kendaraan, modal yang diinvestasikan dalam kendaraan dan peralatan, dan kegiatan administrasi. Selain konsumsi sumber daya keuangan, risiko kehilangan dan kerusakan produk selama aktivitas transportasi juga dapat menimbulkan biaya atau kerugian yang signifikan. Maka diperlukan pengaturan keuangan.

3. Penyimpanan Produk

Transportasi berperan dalam penyimpanan produk, terutama penyimpanan sementara dari lokasi asal pengiriman ke lokasi tujuan. Fungsi penyimpanan sementara ini lebih ekonomis dilakukan dalam kegiatan transportasi, terutama untuk pemenuhan kesediaan barang-barang yang terjadwal dengan waktu pengiriman dalam beberapa hari. Biaya-biaya yang mungkin terjadi seperti biaya muat barang (loading), pergudangan, dan bongkar barang (unloading) dari penyimpanan sementara produk mungkin lebih besar bila dibandingkan dengan biaya penggunaan kendaraan yang difungsikan untuk penyimpanan sementara.

- Margin

Hasil yang didapatkan dari aktivitas utama dan aktivitas pendukung dari proses bisnis yang sedang berjalan di PT XYZ adalah dapat menentukan vendor yang efisien yang sesuai dengan perusahan.

Uraian tugas dari masing-masing jabatan yang terkait dengan sistem informasi dan pengecekan kesesuaian pembagian tugas dengan prinsip-prinsip pengendalian internal adalah sebagai berikut:

1. Head of Logistic

Head of Logistic bertugas memberi persetujuan layak atau tidak suatu perusahaan untuk menjadi vendor PT XYZ.

2. Trucking Manager

Trucking Manager betugas menentukan harga dan melakukan penawaran untuk setiap layanan yang ditawarkan oleh vendor Logistics Department. 


\section{Trucking Supervisor}

Trucking Supervisor bertugas meninjau atau melakukan survey lapangan untuk menentukan Armada Angkutan yang dimiliki vendor dalam keadaan baik atau ada gangguan sehingga diragukan angkutannya.

4. Tender Admin

Tender Admin bertugas melakukan penyortiran proposal dan pemeriksaan kelengkapan dokumen bagi vendor yang mengikuti tender

5. General Admin / Billing Admin

General Admin / Billing Admin bertugas membuat rekapitulasi tagihan dari vendor

Untuk menggambarkan proses bisnis yang ada digunakan business process modeling notation (BPMN) [11], untuk memodelkan proses pada sistem sedang berjalan yaitu pada proses bisnis Seleksi Vendor Berdasarkan Kelengkapan Administrasi, Penilaian Armada Angkutan, Penentuan Harga dan Pembuatan Rekapitulasi Tagihan. Sebagai contoh berikut penggambaran proses bisnis penilaian armada angkutan yang dilakukan perusahaan. Dalam prosedur menilai armada angkutan yang dimiliki vendor terdapat tiga aktor yang terkait yaitu Trucking Manager, Trucking Supervisor, dan Tender Admin. Adapun kegiatan yang terjadi dalam penilaian armada angkutan vendor digambarkan pada gambar 3.

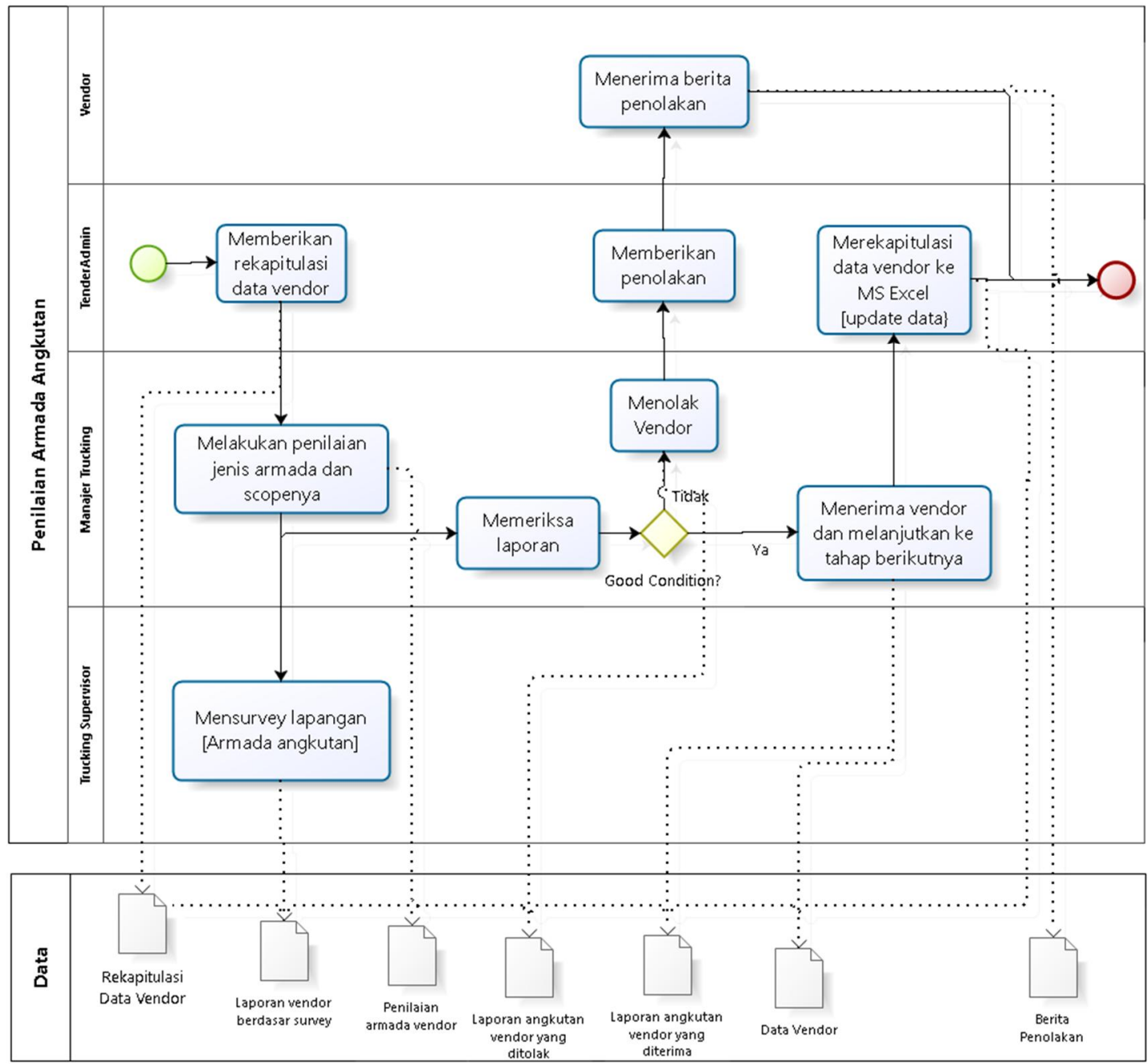

Gambar 3. Proses Penilaian Armada Angkutan 
Keterangan:

1. Tender Admin memberikan rekapitulasi data vendor yang telah dikualifikasikan sebagai vendor yang memiliki kelengkapan administasi yang sesuai kebutuhan kepada Trucking Manager.

2. Trucking Manager akan melakukan penilaian mengenai armada angkutan yang dimiliki setiap vendor baik itu dari legalitas kepemilikan angkutan, QHSE. Kemudian untuk memastikan penilaian tersebut Trucking Manager akan menyerah hasil dari penilaian yang dilakukannya kepada Trucking Supervisor untuk dilakukan survey lapangan.

3. Trucking Manager akan mensurvey atau meninjau langsung armada yang dimiliki vendor untuk menghindari penipuan dan keraguan yang mungkin terjadi di bagian trucking. Selanjutnya hasil dari peninjauan tersebut dilaporkan kepada Trucking Manager.

4. Trucking Manager memeriksa laporan dari Trucking Supervisor dan memutuskan apa vendor-vendor tersebut dapat menuju ke pengkualifikasian berikutnya atau tidak.

5. Jika ada kekurangan maka vendor tereliminasi. Selanjutnya data mengenai penilaian armada vendor diberikan kepada Tender admin untuk diolah lagi.

6. Tender admin akan membuat pemberitaan mengenai penolakan vendor dan memberikan informasi tersebut kepada vendor-vendor yang ditolak.

7. Vendor akan menerima berita penolakan

8. Jika keadaan armada angkutan serta layanan yang diberikan untuk armada tersebut dinilai baik maka vendor tersebut diterima dan dapat menuju ke prosedur selanjutnya.

9. Kemudian membuat rekapitulasi data vendor yang diterima dengan membuka kembali file rekapitulasi data vendor dan menambahkan data baru lalu disimpan kembali.

10. Proses selesai.

\subsection{Perancangan Sistem}

Rancangan trucking collaboration system merupakan rancangan perangkat lunak dibangun untuk membantu Logistic Department dalam pengelolaan proses memanajemen trucking vendor seperti proses penyortiran proposal, seleksi kelengkapan administrasi vendor dan penilaian armada angkutan vendor, penyimpanan dokumen agreement dalam bentuk digital, pembuatan rekapitulasi tagihan dari vendor, dan kelola data vendor di PT XYZ. Perancangan sistem menggunakan Unified Modeling Language/UML [12]. Sistem yang akan dirancang akan memiliki fitur-fitur berikut ini guna menyesuaikan dengan fungsi kerja setiap aktornya.

1. Validasi Login

2. Pengelolaan Admin

3. Pengelolaan Tender

4. Pengelolaan Pendaftaran dan Seleksi

5. Pengelolaan Data Vendor

6. Pengelolaan Account

7. Pengelolaan Agremeent

8. Pengelolaan Tagihan

9. Pengelolaan Laporan

Perancangan data yang digambarkan dengan use case merepresentasikan sebuah interaksi antara aktor dengan sistem. Gambar 4 merupakan use case dari sistem yang akan dirancang. 


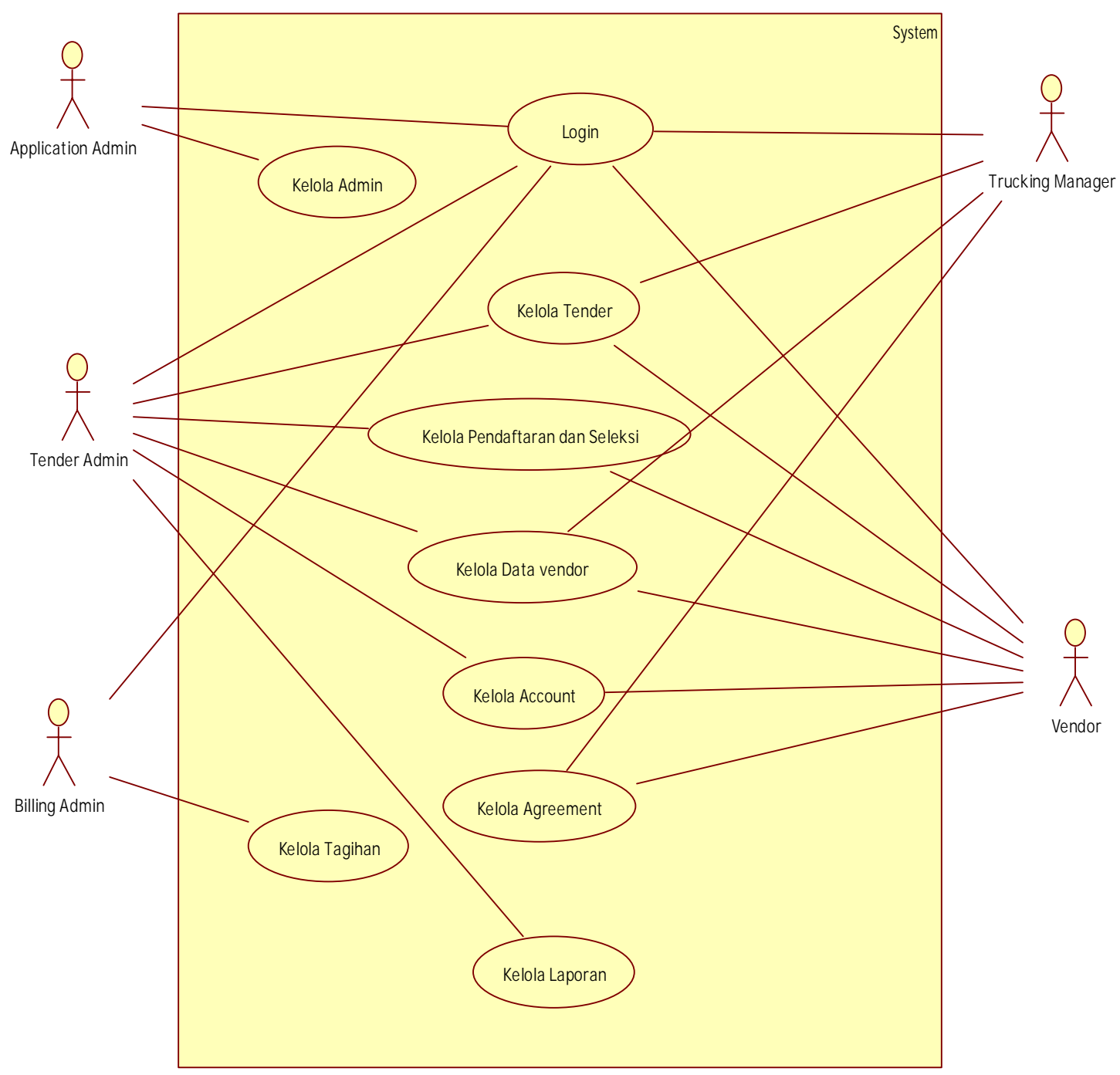

Gambar 4. Usecase Diagram Trucking Collaboration System

Sistem ini terdiri dari lima aktor yaitu:

1. Tender Admin

2. Billing Admin

3. Application Admin

4. Trucking Manager

5. Vendor

Berikut ini adalah desain basis data yang akan dibangun untuk Trucking Collaboration System PT XYZ yang secara garis besar menggunakan tabel-tabel berikut sesuai dengan pemodelannya pada class diagram dan model data seperti disajikan pada tabel 1 dan gambar 5 .

Tabel 1. Daftar Rancangan Tabel pada Aplikasi

\begin{tabular}{|c|l|l|l|}
\hline No & \multicolumn{1}{|c|}{ Nama Tabel } & \multicolumn{1}{c|}{ Jenis } & \multicolumn{1}{c|}{ Primary Key } \\
\hline 1. & Vendor & Tabel Vendor & Kode Vendor \\
\hline 2. & Layanan & Tabel Layanan & Kode Layanan \\
\hline 3. & Cara Pembayaran & Tabel Cara Pembayaran & Kode Cara Pembayanan \\
\hline 4. & Tagihan & Tabel Tagihan & Kode Tagihan \\
\hline
\end{tabular}




\begin{tabular}{|l|l|l|l|}
\hline 5. & Dokumen Vendor & Tabel Dokumen Vendor & Kode Dokumen Vendor \\
\hline 6. & Tbl_Agreement & Tabel Agreement & Kode Agreement \\
\hline 7. & Tbl_Admin & Tabel Admin & Kode Admin \\
\hline
\end{tabular}

Perancangan antarmuka berisi semua perancangan tampilan pada Trucking Collaboration System yang terdiri dari lima pengguna. Pengguna pertama adalah vendor yang melakukan masukkan data profil perusahaan dan dokumen-dokumen terkait. Kedua adalah admin tender yang mengelola data tender, data vendor, data penyeleksian. Ketiga adalah admin billing yang mengelola rekapitulasi tagihan berupa membuat tagihan dan cetak tagihan. Keempat adalah system admin yang mengelola data pengguna sistem dan yang kelima adalah manager yang bertugas mengontrol data-data pada sistem. 
Jatisi

Vol. 7, No. 3, Desember 2020, Hal. 498-509
ISSN 2407-4322

E- ISSN 2503-2933

\section{Class Diagram}

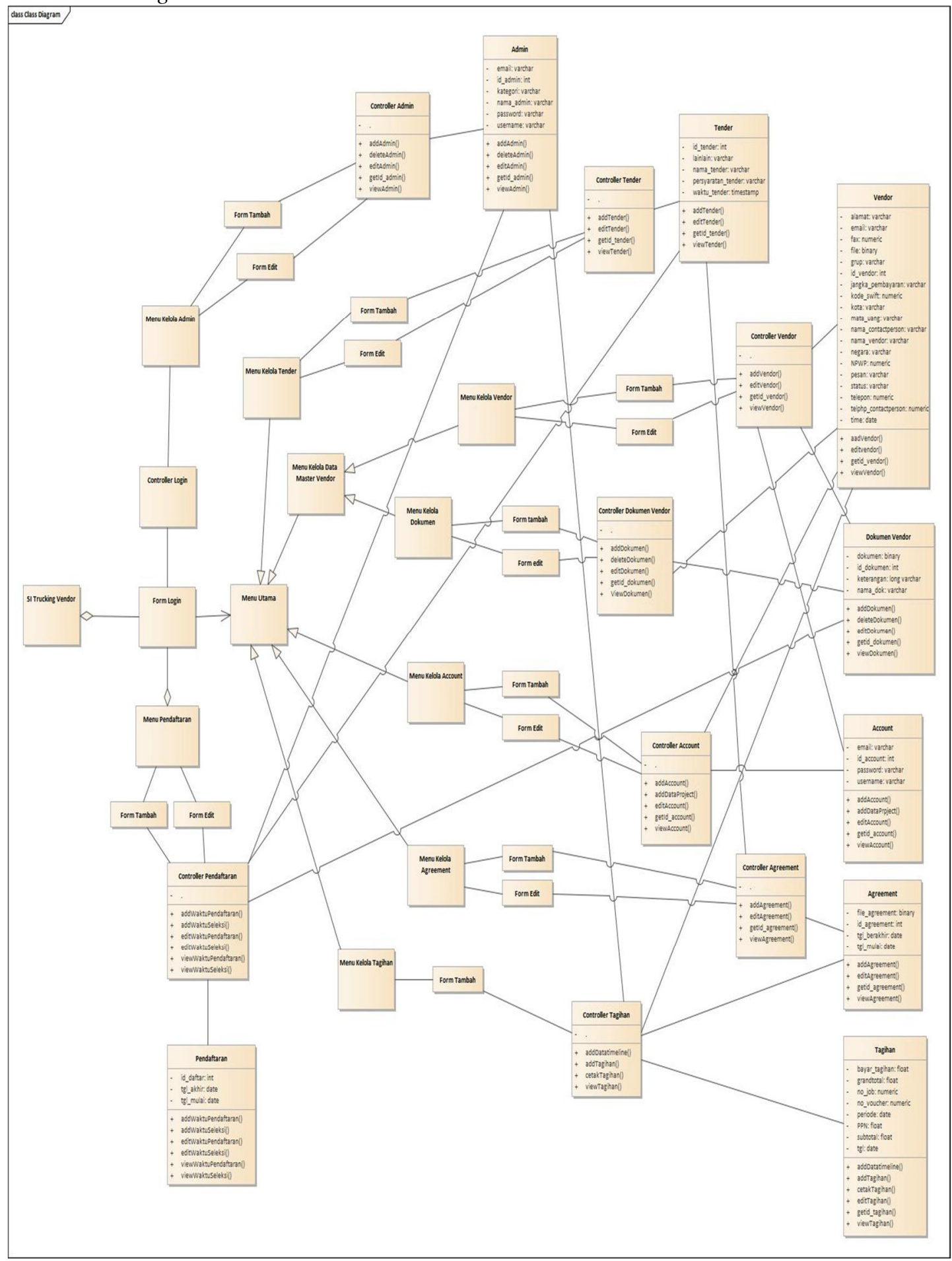

Gambar 5. Class Diagram 


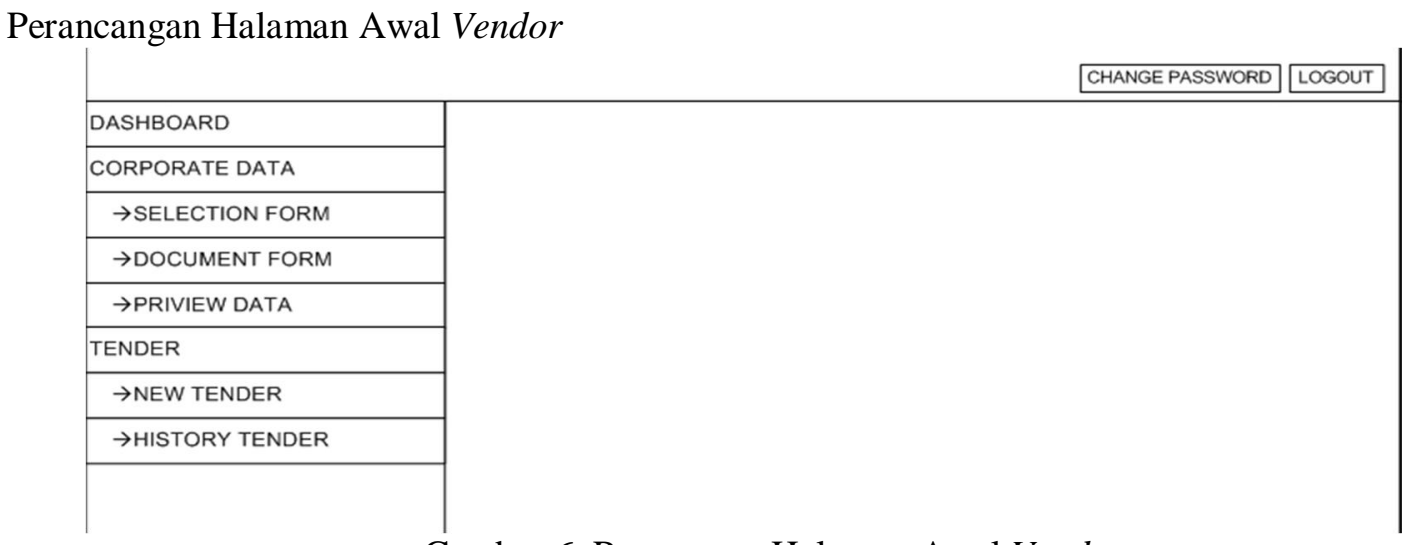

Gambar 6. Rancangan Halaman Awal Vendor

Tampilan Gambar 6 adalah contoh rancangan dari tampilan awal pada saat vendor membuka aplikasi Trucking Collaboration System.

\section{KESIMPULAN}

Simpulan dari penelitian rancangan trucking collaboration system yang dilakukan adalah telah terdefinisi proses bisnis trucking system yang selama ini berjalan di PT XYZ dan terdapat peluang untuk merancang media komunikasi dan transaksi antara perusahaan, vendor dan mitra pemilik barang. Rancangan trucking collaboration system yang dihasilkan didasari dari proses bisnis yang berjalan, arsitektur aplikasi dan dokumentasi kebutuhan fungsional yang formal, memberikan kontribusi berupa arsitektur aplikasi yang dapat dijadikan arahan merealisasikan aplikasi dengan menerapkan rancangan teknologi informasi. Pada tahapan analisis pemodelan yang digunakan menggunakan BPMN, sedangkan pada tahapan perancangan menggunakan UML.

\section{SARAN}

Pada penelitian berikutnya disarankan untuk mengimplementasikan rancangan Trucking Collaboration System berbasis web dan mengevaluasi kembali untuk penambahan fitur pendukung pengambilan keputusan untuk manajemen perusahaan.

\section{UCAPAN TERIMA KASIH}

Penulis mengucapkan terima kasih kepada Politeknik Pos Indonesia yang telah memberi dukungan financial terhadap penelitian ini.

\section{DAFTAR PUSTAKA}

[1] Adinda Saraswati, I. B., 2017, Membangun Supply Chain Resilience Dengan Pendekatan Quality Function Development: Studi Kasus Perusahaan Freight Forwarder, Jurnal Sains dan Seni ITS, Vol. 6, No. 2, ISSN: 2337-3520, D273.

[2] Sutarman, 2017, Dasar-dasar Manajemen Logistik, Refika Aditama, Bandung. 
[3] Krajewska, M. A., \& Kopfer, H. , 2009, Transportation Planning in Freight Forwarding Companies. European Journal of Operational Research, 197(2), 741-751.

[4] Pan, S., 2017, Horizontal Collaboration for Sustainable Transport and Logistics. Business Administration, Université de Valenciennes et du Hainaut-Cambrésis.

[5] Tyan, J.C., Wang, F.K., dan Du, T., 2003, Applying Collaborative Transportation Management Models in Global Third-Party Logistics, International Journal of Computer Integrated Manufacturing, 16:4-5, 283-291, DOI: 10.1080/0951192031000089183

[6] Pateman, H., Cahoon, S, dan Chen, S, 2016, The Role and Value of Collaboration in The Logistics Industry: An Empirical Study in Australia, The Asian Journal of Shipping and Logistics, Vol 32, hal 33-40.

[7] Parimala, K., 2013, Exporters Choice of Freight Forwarder in Moving Their International Cargo, International Journal of Applied Research and Studies, 2(12), 1-8.

[8] Vargas, A, Patel, S. dan Patel, D., 2018, Towards A Business Model Framework to Increase Collaboration in the Freight Industry, Logistics, 2 (4).

[9] Barnes, D., 2001, Understanding Business Processes, The Open University, London.

[10] Porter, M. E., 1985, Competitive Advantage: Creating and Sustaining Superior Performance, Simon and Schuster, New York, ISBN 9781416595847.

[11] Stephen A. White, S.A., dan Bock, C., 2011, BPMN 2.0 Handbook Second Edition: Methods, Concepts, Case Studies and Standards in Business Process Management Notation, Future Strategies Inc, Florida.

[12] Hunt,J., 2000, The Unified Process for Practitioners: Object-Oriented Design, UML and Java. Springer. 